\title{
Lower Dietary Inclusion of Alphamune G May Improve Performance, Hematology, Serum Biochemistry and Histology of Broiler Chicken
}

\author{
S. A. Bolu ${ }^{1}$, K. D. Adeyemi ${ }^{1}$, F. E. Sola-Ojo ${ }^{1}$, A. A. Fabiyi ${ }^{1}$, A. T. Adedeji ${ }^{1}$, O. Oluyemi ${ }^{2}$ \& A. B. Babalola ${ }^{1}$ \\ ${ }^{1}$ Department of Animal Production, University of Ilorin, Ilorin, Nigeria \\ ${ }^{2}$ Vivax ltd, Ikeja Lagos, Nigeria
}

Correspondence: S. A. Bolu, Department of Animal Production, University of Ilorin, Ilorin, Nigeria. E-mail: bolusao2002@yahoo.co.uk

Received: February 13, 2012 Accepted: March 28, 2012 Online Published: July 3, 2012

doi:10.5539/sar.v1n2p15

URL: http://dx.doi.org/10.5539/sar.v1n2p15

\begin{abstract}
A 56-day trial was conducted on 140 day-old broiler chicks fed graded levels of Alphamune $\mathrm{G}(0.00,0.02,0.03$, $0.04,0.05$ and $0.06 \%$ ) in a completely randomized design. Feed intake and weight gain were significantly influenced $(\mathrm{P}<0.05)$ by the inclusion levels of Alphamune G. Bird fed $0.00 \%$ and $0.02 \%$ Alphamune had the highest and lowest feed intake, respectively. There was no significant difference in the feed intake, weight gain and feed to gain ratio of broiler birds fed 0.04 and $0.05 \%$ Alphamune G. Birds fed Alphamune at 0.04 and $0.05 \%$ had the best feed to gain ratio. Broiler chicks fed $0.04 \%$ of Alphamune $\mathrm{G}$ had the highest fibre, fat and ash retention $(68.70,77.46$, and $59.88 \%$, respectively). There was no significant difference $(\mathrm{P}>0.05)$ in the carcass characteristics of birds fed different graded levels of Alphamune G. Haematological parameters show no significant difference among levels of Alphamune G. Serum biochemical values did not show any significant effect except for cholesterol, creatinine and uric acid. Alphamune $\mathrm{G}$ at $0.04 \%$ inclusion in diets may help improve performance of broiler chicken.
\end{abstract}

Keywords: Alphamune G, broiler, haematology, serum

\section{Introduction}

The practice of feeding livestock with sub-therapeutic levels of antibiotics has been in use for a long period (Bolu et al., 2009; Ibekwe et al., 2000; Oluyemi \& Oyagade, 1998). Antibiotics affect gut microflora by altering the metabolism of microorganism thus suppressing microbial growth in the gut (Biedrzycka, 2003; Bolu et al., 2009; Jensen, 1998; Prescott \& Baggot, 1993). Use of antibiotics has been implicated in having negative effects on animal health and human consumers (Bent \& Jesen 2004; Muir, 1998; Noh, 1997). Antibiotic growth promoters have also been reported to have residual effects in tissue long after withdrawal period and development of resistance in microorganism allergy and genotoxicity (Rolfe, 2000; Savage, 1972; Samanta \& Biswas, 1997). Presently, there is a global push to reduce the use of antibiotic as feed additive in farm animals due to concerns on the build-up of antibiotic resistance in human consumer of products from these animals (Patidar \& Prajapati, 1999). Consequently, new concepts aimed at promoting animal health, growth performance, feed efficiency and product quality has been developed (Sims et al., 2004). Example of such concepts involves the use of probiotic, prebiotic, symbiotic and phytobiotic additives. The mode of action of these additives differs. Probiotics when added to diet improve nutrient uptake and counter the effect of harmful microbes in the gut. Its mode of action is competitive exclusion. Prebiotics are non-living food materials which when added to feed are preferred by harmful microbes due their fibrous nature. Phytobiotics involves the use of herbs while symbiotic is the combination of pre and probiotics. Huff (2008) identified Alphamune $\mathrm{G}$ as an alternative to antibiotic growth promoters. It is extracted from Sacchromyces cerevisae that has been spray dried to a tan powder and granulated (Alpharma Animal Health, 2004). Alphamune G exhibits a pre-biotic effect, as a feed supplement, it has been reported to improve the performance and immune-competence of animals (Huff, 2006; Bolu et al., 2009). Alphamune is a combination of 1-3, 1-6 $\beta$-glucans and mannan oligosaccharides. B-glucans has been reported to possess immunomodulatory functions (Bolu et al., 2009). Alphamune supplementation in pig's diet has also been reported to improve performance compared to salinomycin (an Antibiotic Growth Promoter). Bolu et al. (2009) recommended $0.04 \%$, which is lower than the recommended level in broilers diet. They also recommended that further studies should be carried out to ascertain the effects of lower levels of dietary inclusions of Alphamune 
on the performance of broilers The objective of this study was to determine the effects of lower graded levels of Alphamune $\mathrm{G}$ on gut morphology, hematological indices, serum biochemistry, performance characteristics and histology of specific organs of broiler chicken.

\section{Materials and Methods}

One hundred and fifty (150) day-old, mixed sex broilers were used in this study. The chicks were weighed and randomly allotted to six treatment groups of 20 chicks each. The treatments were replicated in five units. Birds were housed in an electrically heated metabolic battery cage. The dietary treatments consisted of six graded levels of Alphamune $\mathrm{G}(0.00,0.02,0.03,0.04,0.05$ and $0.06 \%)$ incorporated into basal diet formulated to meet the nutrient requirement $(\mathrm{NRC}, 1994)$ of broilers (Table 1). Routine management and vaccination were followed (Bolu et al., 2009). Feed and water were given ad libitum for the 8 weeks trial.

Table 1. Composition of the Basal diet (\% DM)

\begin{tabular}{lll}
\hline Ingredient & Starter & Finisher \\
\hline Maize & 50.00 & 55.00 \\
Wheat offal & 6.00 & 12.00 \\
Soya bean meal & 38.00 & 25.00 \\
Fish meal & 2.10 & 5.00 \\
Bone meal & 2.50 & 1.50 \\
Oyster shell & 1.10 & 0.50 \\
Methionine & 0.10 & 0.10 \\
Lysine & 0.10 & 0.10 \\
Salt & 0.30 & 0.30 \\
Vitamin premix & 0.25 & 0.25 \\
Total & 100 & 100 \\
Calculated analysis & & \\
Crude protein $(\mathrm{g} / \mathrm{kg})$ & $23.49 \%$ & $21.63 \%$ \\
Metabolizable energy $(\mathrm{Kcal} / \mathrm{kg})$ & 2914 & 2938 \\
\hline
\end{tabular}

\section{Data Collection}

Feed intake and body weight gain were recorded weekly and used to determine the feed to gain ratio. Nutrient retention was determined during the $3^{\text {rd }}$ week of the experiment. Proximate analysis of the diet and faecal samples were determined according to the method of AOAC (1990). At the end of the trial, eight birds were selected per treatment, fasted overnight and slaughtered by severing the jugular vein for carcass evaluation. The relative weights of different cuts parts and organs were taken and expressed as $\mathrm{g} / 100 \mathrm{~g}$ body weight of the birds. Blood samples were collected from the jugular vein and used for haematological and serological indices according to Maxwell et al. (1990). Samples collected using serology were collected into capillary tubes containing EDTA and later centrifuged at 4000rpm for 3minutes and the resulting sera decanted into bijou bottles. Wintrobes microhaemotocrits improved Neubauer haemocytometer and cyanomethaemoglobins methods were used to estimate cell counts and haemoglobin, respectively. Following carcass analysis, organ required for histological studies were dissected and preserved in $10 \%$ formalin solution. Histological study was carried out in accordance to methods described by Ker et al. (1982). Data obtained from the experimental trial were analyzed using completely randomized design (Steel \& Torrie, 1980). Difference between means was separated using Duncan multiple range test (Duncan, 1955). 


\section{Results and Discussion}

There was significant difference $(\mathrm{P}<0.05)$ in the feed intake, weight gain and feed to gain ratio of broilers fed the various treatments (Table 2). Birds fed the control diet ( $0 \%$ Alphamune) had the highest feed intake. Birds receiving $0.02 \%$ Alphamune had the lowest feed intake. Birds fed Alphamune at 0.04 and $0.05 \%$ had the best feed to gain ratio. Broiler chicks fed $0.04 \%$ of Alphamune $\mathrm{G}$ had the highest fibre, fat and ash retention (68.70, 77.46 , and $59.88 \%$, respectively). The feed intake observed in this study suggests that dietary Alphamune may have aided nutrient digestion, especially energy. Weight gain has been reported as a function of adequate nutrition (Atteh, 2002). NRC (1994) observed that feed intake in poultry is inversely related to the energy content of the diet. Through a feedback mechanism, energy satiety can reduce voluntary feed intake. Broilers fed the control diet did not efficiently utilize the nutrients, as did the birds fed dietary Alphamune. However, lower levels of dietary Alphamune (below 0.04\%) did not improve broiler's performance further. The $0.02 \%$ of Alphamune had the lowest (216.01) weight gain. Bolu et al. (2009) reported that dietary Alphamune at 0.04 and $0.05 \%$ improved the performance of broilers. Nutrient retention of broilers fed the graded levels of Alphamune (Table 2) varied significantly $(\mathrm{P}<0.05)$. Birds receiving $0.04 \%$ of Alphamune $\mathrm{G}$ had the highest $(67.29 \%)$ retention of crude protein, while the birds fed the control diet recorded the lowest value for crude protein. There was significant difference among the treatments with respect to percentage fat retention $(\mathrm{P}<0.05)$. Birds fed $0.04 \%$ Alphamune $\mathrm{G}$ had the highest (77.46\%) fat retention while $0.02 \%$ Alphamune $\mathrm{G}$ had the lowest fat retention (68.62). Fat retention was the similar for broilers fed $0.03,0.05$ and $0.06 \%$ dietary Alphamune. The percentage ash retained was highest for 0.04 and $0.05 \%$ of Alphamune G. There was significant difference $(\mathrm{P}<0.05)$ in the fibre retention of birds fed various levels of dietary treatments. Results showed that birds fed diet containing $0.04 \%$ and $0.05 \%$ Alphamune $\mathrm{G}$ had higher fibre retention of 68.70 while birds fed $0.03 \%$ Alphamune $\mathrm{G}$ had the lowest fibre retention (44.91). Generally, broilers fed dietary Alphamune tended to retain more nutrients, especially at $0.04 \%$, this agreed with the observations of Bolu et al. (2009); below this level of inclusion, nutrient retention was not improved further.

Table 2. Effect of graded levels of Alphamune on performance and nutrient retention of broiler chicks

\begin{tabular}{lllllllll}
\hline $\begin{array}{l}\text { Alphamune } \\
\text { G }(\%)\end{array}$ & $\begin{array}{l}\text { Feed Intake } \\
(\mathrm{g} / \text { bird/week })\end{array}$ & $\begin{array}{l}\text { Weight gain } \\
(\mathrm{g} / \mathrm{bird} / \text { week })\end{array}$ & $\begin{array}{l}\text { Feed/Gain } \\
\text { ratio }\end{array}$ & $\begin{array}{l}\text { Protein } \\
\text { retention } \\
(\%)\end{array}$ & $\begin{array}{l}\text { Ash } \\
\text { retention } \\
(\%)\end{array}$ & $\begin{array}{l}\text { Fat } \\
\text { retention } \\
(\%)\end{array}$ & $\begin{array}{l}\text { Fibre } \\
\text { retention } \\
(\%)\end{array}$ \\
\hline 0.00 & $543.61^{\mathrm{a}}$ & $343.53^{\mathrm{a}}$ & $1.58^{\mathrm{a}}$ & $39.37^{\mathrm{c}}$ & $33.84^{\mathrm{b}}$ & $68.62^{\mathrm{c}}$ & $44.91^{\mathrm{c}}$ \\
0.02 & $299.94^{\mathrm{d}}$ & $216.01^{\mathrm{c}}$ & $1.39^{\mathrm{b}}$ & $55.32^{\mathrm{b}}$ & $20.40^{\mathrm{c}}$ & $67.49^{\mathrm{c}}$ & $49.97^{\mathrm{c}}$ \\
0.03 & $397.14^{\mathrm{c}}$ & $303.23^{\mathrm{b}}$ & $1.31^{\mathrm{b}}$ & $48.63^{\mathrm{b}}$ & $28.46^{\mathrm{c}}$ & $70.56^{\mathrm{b}}$ & $44.93^{\mathrm{c}}$ \\
0.04 & $357.14^{\mathrm{c}}$ & $333.14^{\mathrm{a}}$ & $1.07^{\mathrm{c}}$ & $67.29^{\mathrm{a}}$ & $59.88^{\mathrm{a}}$ & $77.46^{\mathrm{a}}$ & $68.70^{\mathrm{a}}$ \\
0.05 & $366.30^{\mathrm{c}}$ & $328.98^{\mathrm{a}}$ & $1.02^{\mathrm{c}}$ & $56.60^{\mathrm{b}}$ & $58.09^{\mathrm{a}}$ & $72.44^{\mathrm{b}}$ & $68.70^{\mathrm{a}}$ \\
0.06 & $450.70^{\mathrm{b}}$ & $343.67^{\mathrm{a}}$ & $1.31^{\mathrm{b}}$ & $59.42^{\mathrm{a}}$ & $35.49^{\mathrm{b}}$ & $72.03^{\mathrm{b}}$ & $63.61^{\mathrm{b}}$ \\
\hline
\end{tabular}

Table 3. Effect of graded levels of Alphamune $\mathrm{G}$ on carcass characteristics of broiler chicken $(\mathrm{g} / 100 \mathrm{~g}$ body weight)

\begin{tabular}{llllllllll}
\hline Alphamune G (\%) & Thigh & Drum stick & Neck & Wings & Breast & Leg & Back & Head & Dressing \% \\
\hline 0.00 & 15.16 & 13.08 & 6.44 & 10.10 & 20.75 & 7.33 & 13.77 & 3.67 & 75.31 \\
0.02 & 10.70 & 12.14 & 4.35 & 9.53 & 19.57 & 6.35 & 10.70 & 4.35 & 75.83 \\
0.03 & 10.43 & 13.37 & 3.75 & 9.49 & 18.12 & 5.22 & 10.44 & 2.84 & 75.08 \\
0.04 & 13.40 & 13.40 & 5.66 & 9.52 & 19.05 & 7.74 & 11.31 & 3.87 & 75.52 \\
0.05 & 11.83 & 13.35 & 4.96 & 10.32 & 18.71 & 8.39 & 15.27 & 3.44 & 74.96 \\
0.06 & 11.18 & 11.18 & 5.78 & 9.25 & 20.43 & 6.55 & 9.25 & 3.09 & 75.48 \\
\hline
\end{tabular}


Table 4. Effect of graded of Alphamune $G$ on haemalogical parameters of broiler chicken

\begin{tabular}{llllllll}
\hline Haematological & \multicolumn{7}{c}{ Graded levels of Alphamune G } \\
\cline { 2 - 8 } Parameter & & $0.00 \%$ & $0.02 \%$ & $0.03 \%$ & $0.04 \%$ & $0.05 \%$ & $0.06 \%$ \\
Packed Cell Volume & $(\%)$ & 27.7 & 25.0 & 24.7 & 25.0 & 29.0 & 24.7 \\
White blood cell & $\left(10^{9} / 1\right)$ & 10.4 & 10.2 & 9.9 & 9.4 & 10.1 & 10.4 \\
Red blood cell & $\left(10^{12} / 1\right.$ & 3.7 & 3.6 & 3.5 & 3.6 & 4.1 & 3.7 \\
Haemoglobin & $(\mathrm{g} / \mathrm{dl})$ & 6.6 & 6.4 & 6.3 & 6.0 & 6.7 & 5.7 \\
Lymphocytes & $(\%)$ & 68.0 & 66.0 & 70.0 & 69.3 & 71.3 & 66.7 \\
Neutrophils & $(\%)$ & 31.3 & 34.0 & 28.6 & 27.5 & 28.3 & 33.3 \\
Eosinophils & $(\%)$ & 0.33 & 0.00 & 0.7 & 0.00 & 0.00 & 0.00 \\
Monocytes & $(\%)$ & 0.00 & 0.00 & 0.00 & 0.00 & 0.00 & 0.00 \\
Basophils & $(\%)$ & 0.33 & 0.00 & 0.66 & 0.00 & 0.00 & 0.00 \\
\hline
\end{tabular}

Table 5. Effect of graded of Alphamune $\mathrm{G}$ on serum biochemical parameters of broiler chicken

\begin{tabular}{llllllll}
\hline Serum biochemical & \multicolumn{7}{c}{ Graded levels of Alphamune G } \\
\cline { 2 - 8 } Parameter & & $0.00 \%$ & $0.02 \%$ & $0.03 \%$ & $0.04 \%$ & $0.05 \%$ & $0.06 \%$ \\
\hline Protein & $(\mathrm{Mmol} / \mathrm{l})$ & 29.7 & 31.7 & 32.8 & 31.9 & 34.7 & 35.7 \\
Albumin & $(\mathrm{Mmol} / \mathrm{l})$ & 12.4 & 12.1 & 13.1 & 11.1 & 11.5 & 10.3 \\
Cholesterol & $(\mathrm{Mmol} / \mathrm{l})$ & $3.7^{\mathrm{d}}$ & $3.3^{\mathrm{cd}}$ & $2.9^{\mathrm{bc}}$ & $2.8^{\mathrm{bc}}$ & $2.7^{\mathrm{ab}}$ & $2.1^{\mathrm{a}}$ \\
Glucose & $(\mathrm{Mmol} / \mathrm{l})$ & 3.1 & 3.3 & 3.4 & 3.4 & 3.2 & 3.4 \\
Uric acid & $(\mathrm{Mmol} / \mathrm{l})$ & $0.2^{\mathrm{a}}$ & $0.3^{\mathrm{b}}$ & $0.2^{\mathrm{a}}$ & $0.2^{\mathrm{a}}$ & $0.2^{\mathrm{a}}$ & $0.2^{\mathrm{a}}$ \\
Creatinine & $(\mathrm{Mmol} / \mathrm{l})$ & $55.2^{\mathrm{c}}$ & $45.9^{\mathrm{b}}$ & $43.6^{\mathrm{b}}$ & $43.2^{\mathrm{b}}$ & $40.7^{\mathrm{ab}}$ & $36.7^{\mathrm{a}}$ \\
Alkaline Phosphatase & $(\mathrm{iu} / \mathrm{l})$ & 46.7 & 48.2 & 50.8 & 52.9 & 48.8 & 51.2 \\
GPT & $(\mathrm{iu} / \mathrm{l})$ & 19.8 & 22.3 & 21.4 & 21.5 & 24.4 & 24.8 \\
GOT & $(\mathrm{iu} / \mathrm{l})$ & 121.2 & 108.1 & 111.7 & 111.1 & 111.8 & 118.4 \\
\hline
\end{tabular}

a,b,c Means having different superscript along the same row are significantly different $(\mathrm{P}<0.05)$

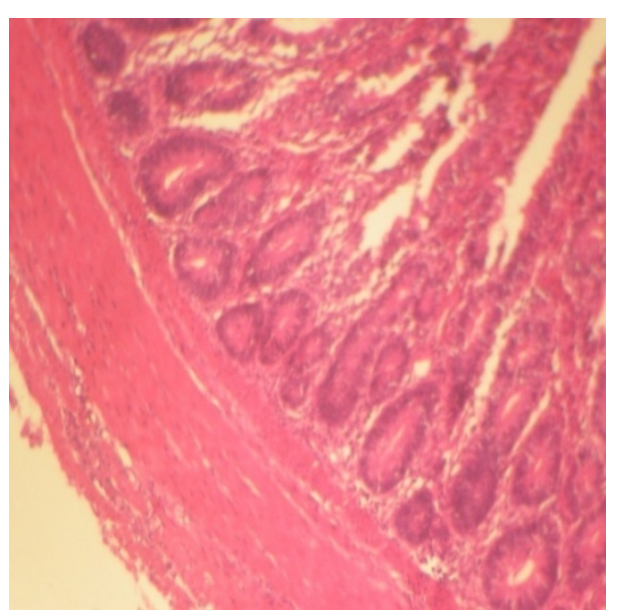

Figure 1. Normal gut of Broiler fed 0.04\% Alphamune (x 60)

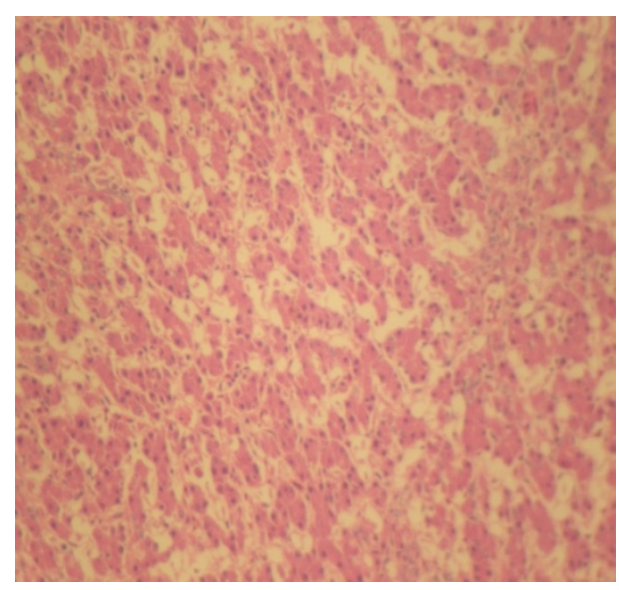

Figure 2. Normal liver of control Broilers (x 40) 


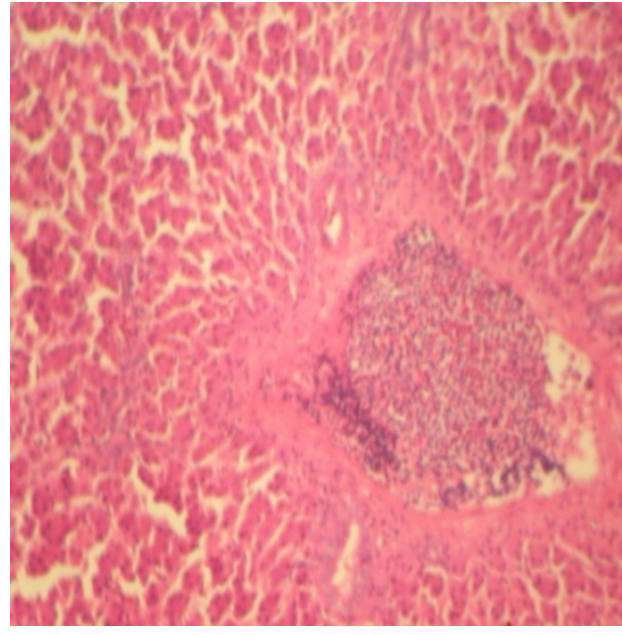

Figure 3. Lymphocytic infiltrations of the liver at $0.04 \%$ Alphamune

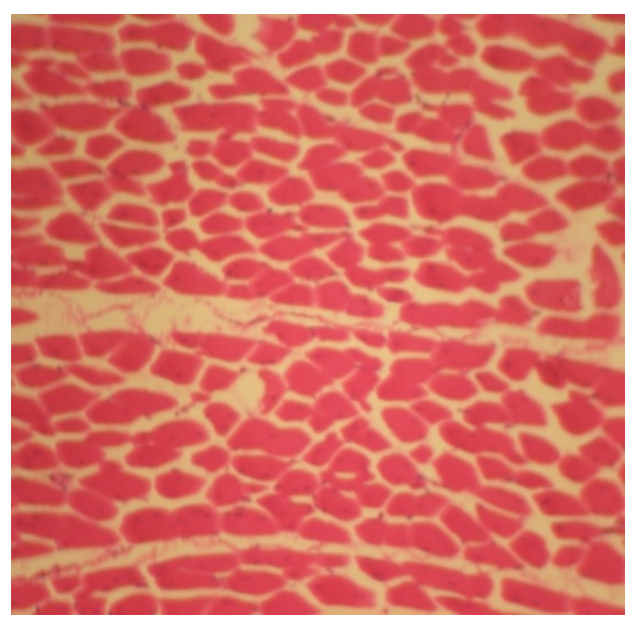

Figure 4. Normal breast muscle of broilers showing lymphocytic infiltrations at $0.04 \%$ Alphamune

Carcass characteristics of bird fed graded levels of Alphamune $\mathrm{G}$ were similar $(\mathrm{P}>0.05)$ (Table 3$)$. The results of the PCV, white blood cells, red blood cells haemoglobin, Neutrophilis, monocytes, eosinophilis and basophils were not significantly different $(\mathrm{P}>0.05)$ among the treatments (Table 4$)$. Serum biochemistry results indicated no significant difference $(\mathrm{P}>0.05)$ for protein, albumin, glucose, alkaline phosphotase, glutamic oxaloacetic transaminase, and glutamic pyruvic transaminases (Table 5). However, there was significant difference $(\mathrm{P}<0.05)$ in the values of serum cholesterol, creatinine and uric acid among the treatments. There was a general increase in serum cholesterol as levels of Alphamune $G$ increases. Results of gut morphology showed normal cell arrangement for the villus in broilers fed Alphamune, especially at $0.04 \%$ (Figure 1), suggesting better nutrient absorption and confirming the results of nutrient retention. The liver of birds from the control treatment had normal tissue (Figure 2). Liver samples from broilers fed Alphamune $G$ showed extensive lymphocytic infiltrations (Figure 3) which agreed with the views of Bolu et al. (2009). Histology of breast muscles however did not marked variation except for lymphocytic infiltrations observed for broilers fed 0.04\% (Figure 4).

\section{Conclusion}

Generally, dietary inclusion of Alphamune in the diet of broilers improved nutrient utilization and contributed considerably to their immunity. The result of this study showed that lower levels of Alphamune (below $0.04 \%$ ) did not improve performance of broilers further. The recommended level of 0.04\% according to Bolu et al (2009) seemed optimum.

\section{References}

AOAC. (1990). Assocaition of Official Analytical chemist Official Method of Analysis. (15th ed.). Washington, DC.

Alphama Animal Health. (2004). Alphamune G. for poultry.

Atteh, J. O. (2002). Principles and practice of Livestock feed manufacturing.

Bent, B., \& Jesen. (2004). Cereal micro flora as affected by dietary fiber of cereals and enzyme supplementation 69 zjad Naukowy OTZ stri. 60.

Biedrzycka, E. (2003). Probiotics as alternative for antibiotics. J. Antimicrobial. Chemoteraphy, 52, 489-492.

Bolu, S. A., Ojo, V., Oyeleke, B. A., Ajiboye, A. O., Baasambo, A., \& Oluyemi, O. (2009). Response of broiler chicks fed graded levels of Alphamune G Supplementation. Int. J.Poultry Sci, 8(1), 32-34. http://dx.doi.org/10.3923/ijps.2009.32.34

Duncan, D. B. (1955). Multiple range and multiple F.test Biom., 11, 1-42.

Huff, G. R., Huff, W. E., Rath, N. C., \& Tellez, G. (2006). Limited treatment with B-1, 3/16-glucan improves production values of broiler chickens challenged with Eschericha colli. Poult.Sci., 85, 613-618.

Ibekwe, V. I., Ubochi, K. C., \& Anyanwu, B. N. (2000). Prevalence of Penicilin resistance in organism that cause sexually transmitted disease in Port Harcourt Nigeria. Nig. Int. J Enviro. Health and Human Dev., 12(1), 
41-46.

Jensen, B. B. (1998). The impact of food addictive on the microbial ecology of the gut in pigs. J. Animal and Feed Sci, 7, 45-46.

Muir, W. I. (1998). Avian intestinal immunity: basic mechanisms and vaccine design. Poult.Avian Biology. Rev, 9, 87-106.

Noh, S. H. (1997). Effect of antibiotics, enzyme, yeast, probiotics and beta-agonist on the growth performance and nutrient availability in broilers. Kor. J. Anim. Sci, 36, 630-638.

NRC. (1984). National Resources Council: Nutrient Requirements for poultry. (8th ed.). Washington D.C. National Academic Science Press.

Olayemi, A. B., \& Oyegade, J. O. (1987). Incidence of antibiotic resistance among E.coli isolated from clinical source and river water. Nig. Medical Journal, 17(4), 207-209.

Rolfe, R. D. (2000). The role of prebiotic cultures in the control of gastrointestinal health. J. Nutri, 130, $396-402$.

Pantida, S. K., \& Prajapati, J. B. (1999). Effect of feeding feed addictives, effectiveness and expected modes Lactobacilli on serum antibody titer and faecal of action. J. Anim. Feed Sci, 10, 51-67.

Prescott, J. F., \& Baggot, J. D. (1993). Antimicrobial therapy in Veterinary Medicine, (2nd ed.). Iowa University Press. pp. 564-565.

Samanta, M., \& Biswas, P. (1997). Effect of feeding Streptococcus culture on performance of broilers. J.Interacademia, 1, 118-120.

Savage, D. C. (1972). Associations and physiological interactions of indigenous microorganism and gastrointestinal epithelia. Am. J. Clin. Nutri, 25.

Sims, M. S., Dawson, K. A., Neroman, D. E., Spring, P., \& Hoogell, D. M. (2004). Effects of dietary mannan oligosaccharide, bacitracin methlene disalicyte or both on the live performance and intestinal microbiology of turkeys. Poult. Sci., 83, 11-48.

Steel, R. G. D., \& Torrie, G. H. (1980). Principles and Procedures of Statistics. A biometrical approach. (2nd ed.). McGraw Hill Book Co. New York. 